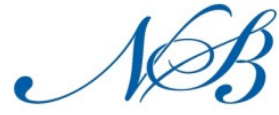

Notulae Scientia Biologicae

\title{
Photographic Key for the Microhistological Identification of Some Plants of Indian Trans-Himalaya
}

\author{
Tanveer AHMED ${ }^{1 *}$, Afifullah KHAN ${ }^{1}$, Pankaj CHANDAN ${ }^{2}$ \\ IAligarh Muslim University, Department of Wildlife Sciences, Aligarh, 202002, India; tanveerwildlife@gmail.com (*correspondingauthor); afifullah.khan@gmail.com \\ ${ }^{2}$ WWF-India, 172-B, Lodhi Estate, New Delhi, 110003, India;pankajchandan@gmail.com
}

\begin{abstract}
Microhistology techniques have been used in many studies regarding food habits of herbivores. The absence of detailed reference materials and time consumed in creating reference plant materials for a particular study species and area hampers an understanding and extensive use of the technique. On the other hand, the use of direct sighting procedure of animals to study the dietary spectrum of herbivores is interrupted by tough terrain and harsh climatic condition in the Trans-Himalaya. The current study provides a photographic key for identification of 38 plants species belonging to 35 genera and 21 families. Structures such as types of stomata, trichomes and epidermal cells are discussed for different species of plants collected from Kargil, Ladakh. The given information is expected to help researchers working on feeding ecology of mammals in the Indian Trans-Himalaya.
\end{abstract}

Keywords: dietary spectrum, feeding ecology, herbivore, microhistology, plant species

\section{Introduction}

Feeding habits of mammals are in the centre of interest of population biology (Lodé, 1996) and ecology (Mátrai et al., 1998). A number of methods have already been evolved and used investigating dietary composition (Holechek et al., 1982; Smith and Shandruk, 1979; Shrestha and Wegge, 2006). One of the indirect techniques for determining diet composition of herbivores is identification of food items through epidermis fragments in the stomach contents or faecal pellets as proposed by Baumgartner and Martin (1939). Later the technique was further advanced by Dusi (1949) and Holechek and Gross (1982) and since then it is being frequently used to study dietary composition of a range of wild and domestic herbivores (Uresk, 1986; Green, 1987; Alipayo, et al., 1992; Ilyas and Khan, 2004; Shrestha et al., 2005; Wegge et al., 2006; Wingard et al., 2011).

Microhistological analysis of plant remains in the faeces has several unique advantages which accounts for its popularity as a research tool (Holechek et al., 1982a; Smith and Shandruk, 1979). There are few shortcomings as well, such as low accuracy depending on herbivore and plant species studied (Caron et al., 1985), sample preparation technique used (Holechek et al., 1982b; Johnson et al., 1983a), observer training (Holechek and Gross, 1982) digestion and fragmentation (Johnson et al., $1983 \mathrm{~b}$ ), number of slides prepared and frequency of observation per slide (Holechek and Vavra, 1981). Furthermore, the absence of detailed reference material or excessive costs in time and effort to create reference material for a particular study species and area mostly hamper a better understanding and extensive use of microhistological techniques (Carrière, 2002). Probably considering this, Satakopan (1972) described a key to the identification of plants remains in animal droppings. Similar efforts were made elsewhere; Hurst and Beck (1988) developed a reference key based on microhistological characteristics of aquatic plants of Florida, Lindstöm et al. (1998) did the same for perennial grass in central Argentina, while Carrière (2002) provided photographic key for the microhistological identification of some Arctic vascular plants. Such reference keys can be of great help to the researchers working on feeding habits of herbivores by reducing time and efforts to develop reference. This paper is also aimed to develop a key for identification of some plant species of Indian Trans-Himalaya by illustrating characters of stomata, trichomes and epidermal cells.

\section{Materials and methods}

Study area

The study was conducted in Rangdum valley (34. $06^{\prime} 55^{\prime \prime}$ to $33^{\circ} 56^{\prime} 32^{\prime \prime} \mathrm{N}$ and $75^{\circ} 57^{\prime} 04^{\prime \prime} \mathrm{E}$ to $\left.76^{\circ} 19^{\prime} 02^{\prime \prime} \mathrm{E}\right)$ situated in the south-western part of Kargil district, Ladakh. The villages within the valley are Panikhar, Achambur, Tangole, Parkachik, Zuildo and Tashi-tonge (Fig. 1). The valley covers an area of $200 \mathrm{~km}^{2}$ between an elevation of 3,245 and 4,550 $\mathrm{m}$. The valley is bounded by Penzilla in the east, the Nun Kun peak in the South, Parkachik in the West and Wakkha Nallah in the North. A combination of arctic and desert type condition prevails in the region, where precipitation is generally in the form of snowfall and rainfall remains less than $100 \mathrm{~mm}$ per year.

The study area support populations of carnivores like snow leopard (Panthera uncia), Himalayan brown bear (Ursus arctos isabellinus), Tibetan wolf (Canis lupus), red fox (Vulpes vulpes), mountain weasel (Mustela altaica) and stoat (Mustela erminea). Herbivore species of the valley include large livestock population along with wild species like Asiatic ibex (Capra ibex), Royle's pika (Ochotona roylei) and plateau 
172
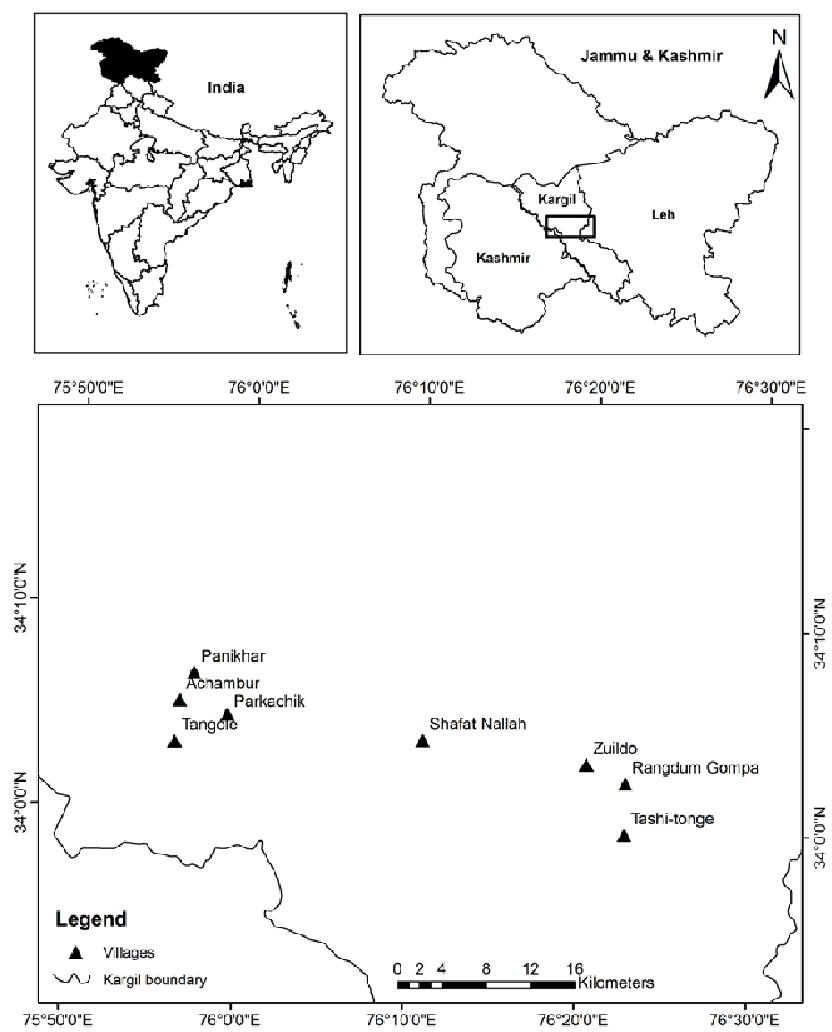

Fig. 1. Outline map of the Kargil

pika (Ochotona curzoniae). Long-tailed marmot (Marmota caudata), Silvery mountain vole (Alticola argentatus) and Stoliczka's mountain vole (Alticola stoliczkanus) represent the rodent community of the valley (Shoeb, 2011).

\section{Methodology}

All potential food plants that were considered to form the diet of herbivores in the study area were collected between May and July 2013 to prepare reference material. Plants species were identified using specialised materials on plants of Ladakh (Polunin and Stainton, 1997; Chaurasia and Singh, 1998; Chaurasia and Singh, 2001; Chaurasia et al., 2008). Two different principles are available for preparing reference material to study microhistological character of plant epidermal fragments. The reference material could either (1) simulate the small and torn appearance of fragments found in animal droppings after ingestion and digestion (e.g. Ellis et al., 1998), or (2) show as many identification features as possible (Johnson et al., 1983b). For diet analysis, reference material must simulate the small fragment found in the sample following mastication and digestion. Hence, first principle was preferred to prepare reference materials of plants following Satakopan (1972).

A few bits of leaves were taken from each food plant sample as stem and vascular tissue are much harder to identify (Green, 1987). They were shredded coarsely and placed in a test tube. Nitric acid along with distilled water (1:3) was added to the material in the test tube. The tube containing the sample plant material was heated and agitated on a low flame for about five to ten minutes. The material was then removed from the flame and was allowed to cool, then again put above the flame for further heating. The heating was continued till the material became transparent. The duration of the warming/heating of material depended on the hardness of the plant species; hard plants required more time to become transparent, while the soft and young plants took less time. The tube was allowed to cool, the liquid drained off and washed repeatedly in distilled water. All the transparent material was poured in a petri dish. Then a few pieces of transparent plant material were taken and dehydrated by passing through the grades of absolute alcohol (AA) and distilled water (DW) mixture (AA:DW; 1:3, 1:1, 3:1) and finally through the absolute alcohol. After dehydrating, the transparent plant material was treated with safranine stain solution and then washed with absolute alcohol to remove excess colour. After this plant specimen was put on the slide and was left for few seconds till it was dried properly. Finally the specimen was mounted using Canada balsam. After mounting, the diagnostic features were recorded by photomicrography using a digital microscope. Broad anatomical features of leaf e.g. stomata, trichomes, epidermal cells and cell wall were focused and their characters were noted. Stomata were classified following Prabhakar(2004). Trichomes were categorised as glandular and non glandular (Johnson et al., 1983a). Epidermal cells were categorised on the basis of their shape e.g. rectangular, angular, lobed and angular to lobed.

\section{Results and discussions}

Histological characters of 38 plants species were investigated and the data showed they are belonging to 35 genera and 21 families (Table 1). Only broad anatomical features e.g. epidermal cell, stomata and trichomes were observed. These broad anatomical characters proved to help in recognition of species (Yagueddú et al., 2009) and have also been used earlier to identify food plant species (Ilyas and Khan, 2004).

Four types of stomata e.g. anomocytic, isotricytic, paracytic and diacytic were observed. Anomocytic stomata were found in 23 species belonging to families Berberidaceae, Boraginaceae, Brassicaceae, Gentianaceae, Geraniaceae, Lamiaceae, Leguminosae, Onagraceae, Orobanchaceae, Papaveraceae, Polygonaceae, Ranunculaceae, Rosaceae, Scrophulariaceae. Paracytic stomata were observed in 11 species belonging to families Convolvulaceae, Colchicaceae, Amaryllidaceae, Brassicaceae, Boraginaceae, Leguminosae, Apiaceae, Ranunculaceae, Leguminosae and Asteraceae. Isotricytic stomata were observed in two species of Polygonaceae and Gentianaceae. Only one family, Caryophyllaceae, contained diacytic stomata (Table 1).

All member of family Ranunculaceae (5 species) contained anomocytic stomata, except one species Delphinium brunonianum which had paracytic stomata. Javed et al. (2012) also reported the presence of anomocytic stomata in this family. Species belonging to Leguminosae contained two types of stomata, anomocytic (3 species) and paracytic (2 species). Similar finding were also advocated in various members of this family (Saheed and Illoh, 2010). Among the members of Polygonaceae, anomocytic and isotricytic stomata were observed. Metcalfe and Chalk (1950) described that stomata in Polygonaceae were nearly always of anomocytic type in Polygonaceae, while Yasmin et al. (2010) 
Table 1. Identification key of some plants of Kargil, Indian Trans-Himalaya

\begin{tabular}{|c|c|c|c|c|}
\hline & Group A stomata present, cells present, trichomes absent & & & Fig. No. \\
\hline \multirow[t]{12}{*}{$\mathrm{Al}$} & Anomocytic stomata & & & \\
\hline & Angular to lobed epidermal cells & Trifolium repens & Leguminosae & 2.a \\
\hline & & Pedicularisbicornuta & Orobanchaceae & 2.b \\
\hline & Angular with linear cell wall & Corydaliscrassifolia & Papaveraceae & $2 . c$ \\
\hline & & Epilobium latifolium & Onagraceae & 2.d, 2.e \\
\hline & & Oxyria digyna & Polygonaceae & $2 . f$ \\
\hline & Lobed with sinous anticlinal & Drabaamoena & Brassicaceae & $2 . g$ \\
\hline & & Thymusserpylium & Lamiaceae & 2.h \\
\hline & & Anemonespp. & Ranunculaceae & $2 . \mathrm{i}$ \\
\hline & & Gentianellapaludosa & Gentianaceae & 2.j \\
\hline & Lobed with wavy cell wall & Meconopsis aculeate & Papaveraceae & $2 . k, 2.1$ \\
\hline & & Podophyllum hexandrum & Berberidaceae & 3.a,3.b \\
\hline \multirow[t]{3}{*}{$\mathrm{A} 2$} & Isotricytic stomata & & & \\
\hline & Angular with linear cell wall & Rheum spiciforme & Polygonaceae & 3.c \\
\hline & Lobed with weakly sinous anticlinal & Exacum tetragonum & Gentianaceae & 3.d \\
\hline \multirow[t]{7}{*}{ A3 } & Paracytic stomata & & & \\
\hline & Angular to lobed with linear cell wall & Dactylorhiza hatagirea & Orchidaceae & 3.e \\
\hline & & Convolvulusarvensis & Convolvulaceae & 3.f \\
\hline & Rectangular with linear cell wall & Colchicum luteum & Colchicaceae & $3 g$ \\
\hline & & Allium carolinianum & Amaryllidaceae & 3.h \\
\hline & Lobed with linear cell wall & Drabagracillima & Brassicaceae & $3 . \mathrm{i}$ \\
\hline & Group B: Stomata present, cells visible, trichomes present & & & \\
\hline \multirow[t]{17}{*}{ B2 } & Anomocyticstomata & & & \\
\hline & Angular with linear cell wall & & & \\
\hline & Non glandular, long, ligulate trichomes with one celled base and blunt tip & Oxytropislapponica & Leguminosae & 3.j \\
\hline & Nonglandular, long, erect, ligulate trichomes & Geranium pratense & Geraniaceae & $3 . \mathrm{k}$ \\
\hline & Nonglandular, long, smooth ribbon like trichomes & Anemonereplica & Ranunculaceae & $3.1,4 a$ \\
\hline & Nonglandular, medium sized trichomes with blunt tip & Cynoglossum glochidiatum & Boraginaceae & $4 . \mathrm{b}$ \\
\hline & Non glandular, medium sized trichomes with pointed tip and one celled base & Ranunculusbrothersii & Ranunculaceae & 4.c \\
\hline & Non glandular small, nail shaped trichomes with pointed tip and broad base & Aconogonum molle & Polygonaceae & 4.d, $4 . \mathrm{e}$ \\
\hline & Non glandular, unicellular to segmented trichomes with pointed tip & Marrubium vulgare & Lamiaceae & $4 . \mathrm{f}, 4 \mathrm{~g}$ \\
\hline & Lobed with smooth linear cell wall & & & \\
\hline & Nonglandular, medium multicellular tube like trichomes & Aquilegiafragrans & Ranunculaceae & $4 . \mathrm{h}$ \\
\hline & Lobed with sinous anticlinal cell wall & & & \\
\hline & Nonglandular, longJumble unicellular tube like trichomes & Potentilla eriocarpa & Rosaceae & 4.i, \\
\hline & Lobed with wavy cell wall & & & \\
\hline & Nonglandular, compound trichomes (Branched) & Verbascum thapsus & Scrophulariaceae & $4 . j$ \\
\hline & Medium, unicellular sword like ligulate trichomes & Delphinium cashmerianum & Ranunculaceae & 4.k, 4.1 \\
\hline & Glandular, multicellular trichomes with one celled base and bulbous tip & Cicermicrophyllum & Leguminosae & $5 . a, 5 . b$ \\
\hline \multirow[t]{3}{*}{ B2 } & Diacyticstomata & & & \\
\hline & Angular with linear cell wall & & & \\
\hline & Non glandular, medium, unicellular, ligulate and smooth trichomes & Silene edgeworthii & Caryophyllaceae & 5.c,5.d \\
\hline \multirow[t]{12}{*}{ B3 } & Paracyticstomata & & & \\
\hline & Angular to lobed with linear cell wall & & & \\
\hline & Non glandular, small to long ligulate trichomes with pointed tip and base & Arnebia euchroma & Boraginaceae & 5.e, $5 . f$ \\
\hline & Angular with linear cell wall & & & \\
\hline & Nonglandular, medium sized wavy trichomes with pointed tip & Melilotus officinalis & Leguminosae & $5 . \mathrm{g}, 5 . \mathrm{h}$ \\
\hline & Lobed with wavy cell wall & & & \\
\hline & Non glandular, ligulate trichome, sword like with pointed tip & Selinum tenuifolium & Apiaceae & $5 . \mathrm{i}$ \\
\hline & Lobed with sinous anticlinal & & & \\
\hline & $\begin{array}{l}\text { Glandular,Long, straight, ligulate trichomes with pointed tip and long trichomes } \\
\text { with a pointed tip and bulbous or pot like base }\end{array}$ & Delphinium brunonianum & Ranunculaceae & $5 . j, 5 . \mathrm{k}$ \\
\hline & Unicellular, medium sized trichomes & Lindelfiastylosa & Boraginaceae & 5.1 \\
\hline & Epidermal cells not clearly visible & & & \\
\hline & Non glandular, thin ribbon like trichomes & Taraxacum officinale & Asteraceae. & 6.a, $6 . b$ \\
\hline \multirow[t]{3}{*}{ B4 } & Stomata not clearly visible & & & \\
\hline & Not clearly visible & & & \\
\hline & Non glandular multicellular trichomes with pointed tip and one celled base & Astragalus rhizanthus & Leguminosae & 6.c \\
\hline
\end{tabular}


174

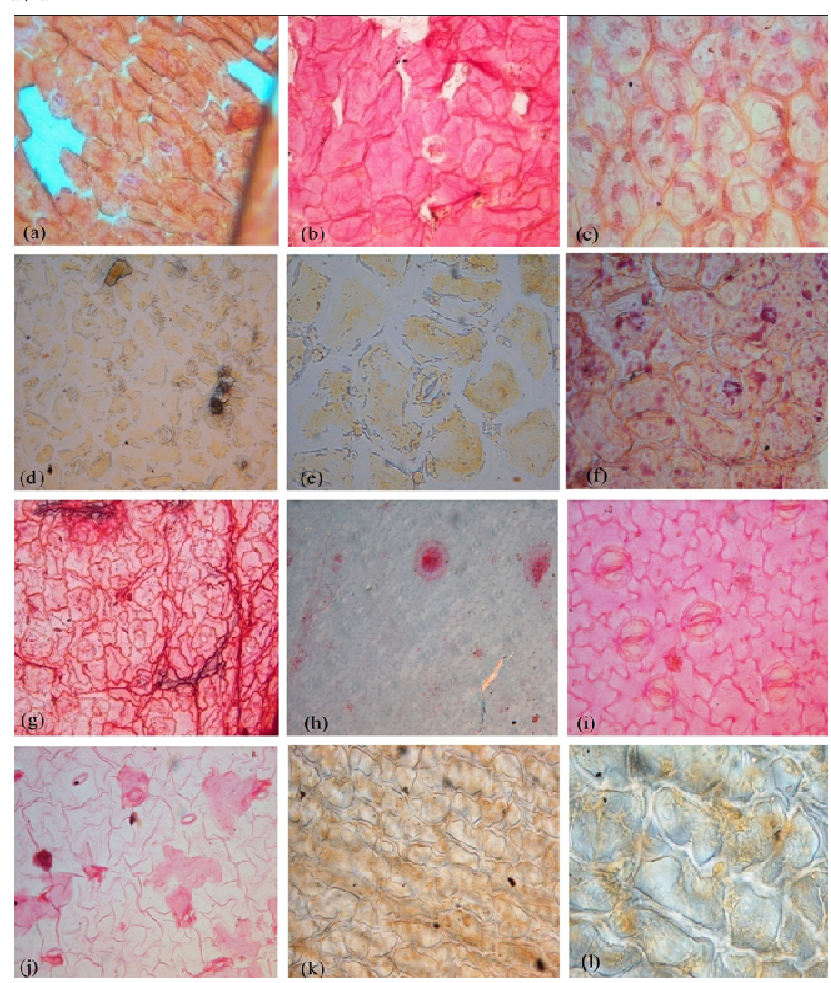

Fig. 2. a. Trifolium repens; b. Pedicularis bicomuta; c. Corydalis crassifolia; $\mathrm{d}$. Epilobium latifolium (Cells); e.Epilobium latifolium (Stomata); f. Oxyria dignna;g Draba amoena; h. Thymus serpylium; i. Anemone spp.; j. Gentianella paludosa; k. Meconopsisaculeate (Cells); L.Meconopsisaculeate(Stomata)
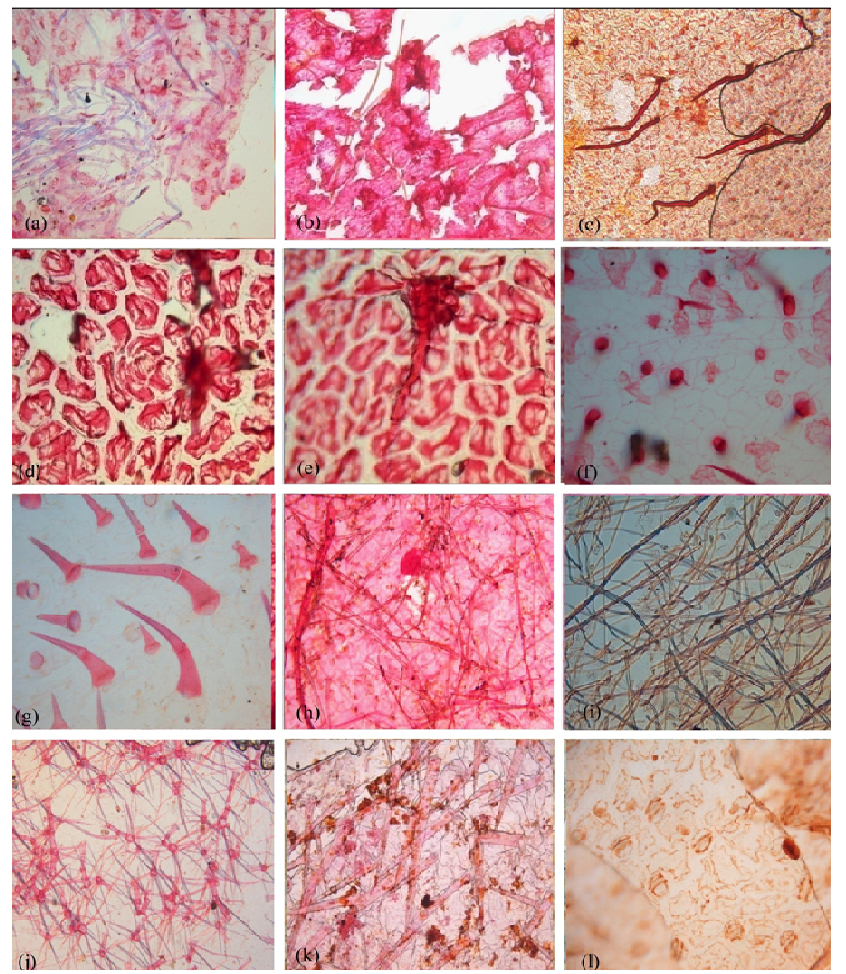

Fig 4. a. Anemone replica (Trichomes); b. Cynoglossum glochidiatum; c. Ramunaulus brothersï; d. Aconogonum molle (Cells); e. Aconogonum molle (Trichome); f Mamubium vulgane(Cells);g Mamubiumvulgane(Trichomes); h.Aquilagiafragrans; i Potentilla eriocarpa (Trichomes); j. Verbascum thapsus $\mathrm{k}$. Delphinium cashmeriamum (Trichomes);1:Delphinium casbmeriamum (CellsandStomata)

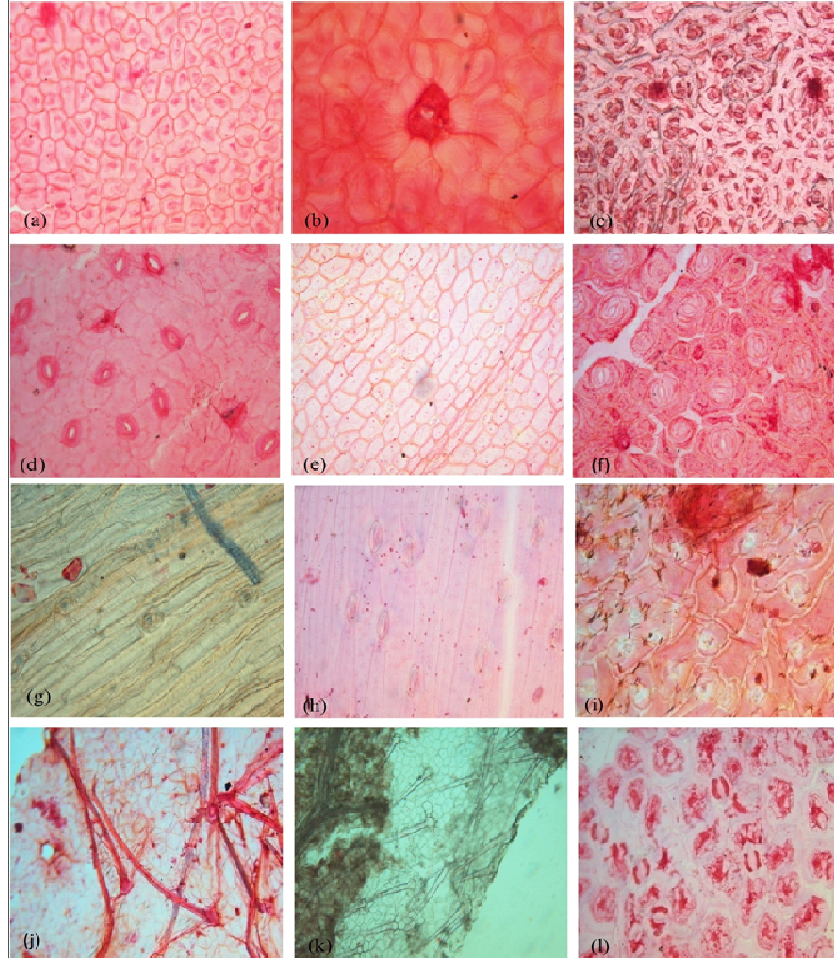

Fig. 3.a.Podophyllum hexandrum (Cells); b.Podophyllum hexandrum (Stomata); c. Rheum spiciforme; d. Exacum tetragonum; e. Dactylonhiza hatagirea; $\mathrm{f}$. Convolurulus arvensis; g. Coldhicum luteum; h. Allium carolinianum; i. Draba gracillima;j.Oxytropis lapponica; k. Geraniumpratense; L.Anemonereplica (Cells)
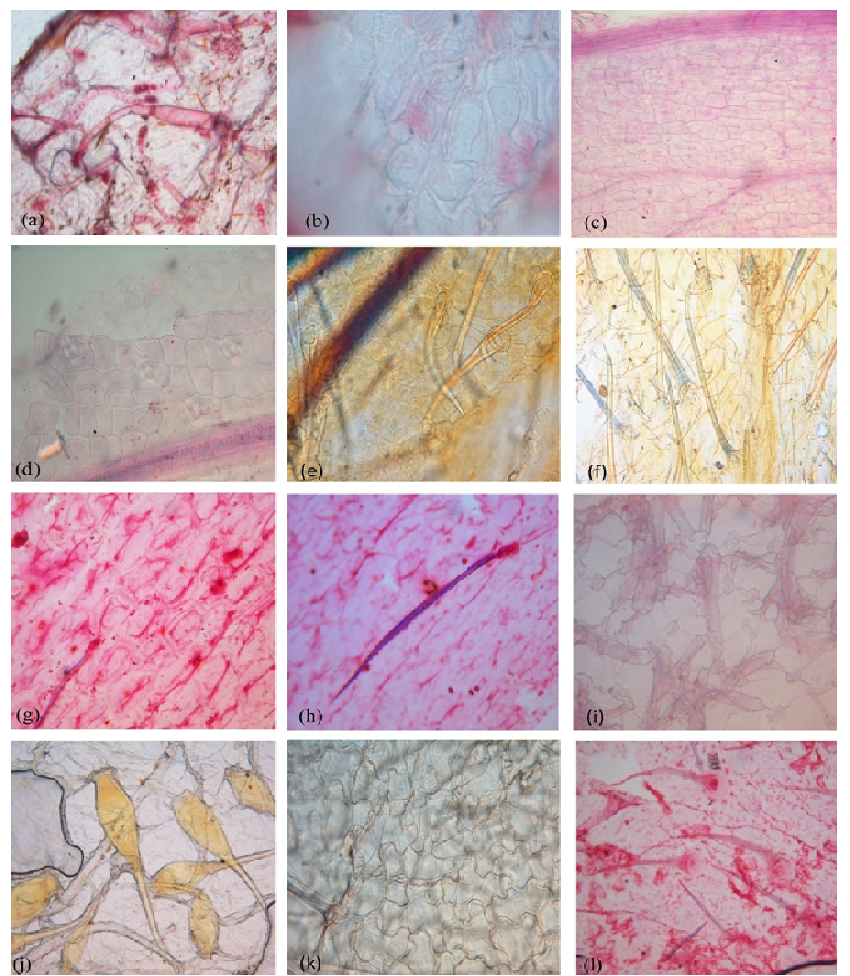

Fig 5.a Cicermicophyllhom (Trichomes); b. Cicermicophyyllum (Cells andStomata); c Silene edgeworthï (Cells); d. Silene edgeworthï (Stomata); e. Amebia eudhoma (Trichomes); f Amebiaeudhroma (Celland Trichomes);gMelilotusofficinalis(Cells); h Melilotus officinalis (Trichome); i. Selinum tenuifolium; j. Delphinium brunoniamum (Trichomes);k Delphiniumbrnmoniamum (Cells); l Lindelofiastylosa(Trichome) 

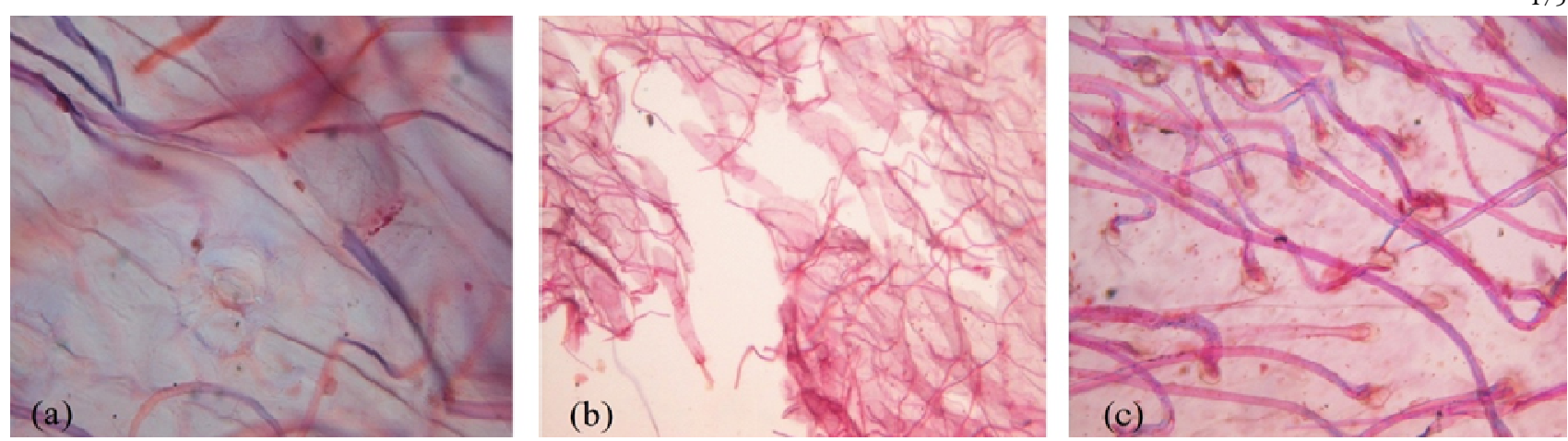

Fig. 6. a. Taraxacum officinale (Stomata); b. Taraxacum officinale(Trichomes); c. Astragallus rhizanthus

observed variability among stomata types within this family. Members of family Lamiaceae (2 species) and Papavaraceae had anomocytic stomata only. Brassicaceae contained anomocytic and paracytic stomata, while Gentianaceae contain anomocytic and isocytic stomata.

Four types of epidermal cells were recorded in the examined species. These were angular, angular to lobed, lobed and rectangular. The lobed epidermal cells were observed in 16 species (Figs. 1g-1l, 2a-2b, 2d, 2i, 3h-3l, 4a, 4b and 4i-4l), angular in 13 species (Figs. 1c-1f, 2c, 2j-2k, 3a-3g, 4c-4d and 4g-4h), angular to lobed in five species (Figs. 1a, 1b, 2e, 2f, 4e and 4f) and rectangular in two species (Figs. $2 \mathrm{~g}$ and $2 \mathrm{~h}$ ). The epidermal cells were not clearly visible in two species e.g. Taraxacum officinale and Astragalus rhizanthus (Figs. 5b and 5c). Lobed epidermal cells were observed in Berberidaceae, Apiaceae, Boraginaceae, Brassicaceae, Gentianaceae, Lamiaceae, Leguminosae, Papaveraceae, Ranunculaceae, Rosaceae and Scrophulariaceae. Angular cells were present in Boraginaceae, Geraniaceae, Lamiaceae, Leguminosae, Polygonaceae, Ranunculaceae, Caryophyllaceae and Onagraceae. Angular to lobed epidermal cell were present in Leguminosae, Orobanchaceae, Boraginaceae, Convolvulaceae and Orchidaceae. Amaryllidaceae and Colchicaceae contained rectangular cells. However, in two members of Asteraceae and Leguminosae epidermal cell were not visible.

The shape and number of cells making up a trichome is the best starting point for identifying a dicot species (Johnson $e t$ al., 1983a). Characters such as size of the base, shape of the apex, texture of the surface and degree of tapering are useful in identification. Two types of trichomes, glandular and non glandular, were observed having various shapes, like ligulate, ribbon like, nail shaped, tube like, compound, branched and sword like (Table 1). Cicer microphyllum and Delphinium brunonianum belonging to families Leguminosae and Ranunculaceae respectively contained glandular trichomes, while the rest 36 species had non glandular trichomes. Saheed and Illoh (2010) also confirmed the occurrence of glandular trichomes in family Leguminosae. The presence of glandular trichomes in the genus Delphinium had earlier been reported (Torres et al., 2000).

\section{Conclusions}

The purpose of this study is to provide a set of illustrations to identify plant species in the faecal remains of mammals inhabiting Kargil and Ladakh regions of Trans-Himalaya at an altitude of $3,500 \mathrm{~m}$ ASL and above, which is also a prime habitat of snow leopard. The Asiatic ibex, Ladakh urial, long tailed marmot, pica and livestock form the prey base of snow leopard.
There are evidences of competition for food between ever increasing livestock population and naturally occurring prey species and therefore monitoring population status of prey species and their interaction with habitat is central to the management of natural prey base of snow leopard. However, the harsh climatic condition and rough terrain of the study area hamper food habits studies through direct observation in the region. Microhistology is a widely used procedure to study the food habits of mammals around the world through indirect observations. The researchers are making efforts to carry out studies on dietary spectrum of different prey species and in doing so they have to spend a great deal of time and labour to collect plant material and subsequently develop reference catalogue to identify species in the remains of animal faeces. Using this key, food habits of snow leopard's prey base can be investigated with relative ease and it is expected to save researchers' time that can be devoted in setting conservation targets.

\section{Acknowledgements}

Authors are grateful to WWF India for providing infrastructural support which facilitated the field work. Our special thanks to Mr. Ravi Singh, Secretary General and CEO, WWF-India and Dr. Sejal Worah, Programme Director, WWF-India for their support and encouragement to work in Ladakh. Thanks are due to Mr. Jigmet Takpa, CCF and Regional Wildlife Warden, Ladakh and Mr. Abdul Rauf, Wildlife Warden, Department of Wildlife Protection Leh for granting permission to work in the area. We are also thankful to Prof. Jamal A. Khan, Chairman, Dept of Wildlife Sciences, A.M.U. Aligarh for providing library and laboratory facilities to carry out this study.

\section{References}

Alipayo D, Valdez R, Holechek JL, Cardenas M (1992). Evaluation of microhistological analysis for determining ruminant diet botanical composition. Journal of Range Management 45:148-152.

Baumgartner LL, Martin AC (1939). Plant histology as an aid in squirrel food-habitat studies. The Journal of Wildlife Management 3:266-268.

Caron L, Garant Y, Bergeron JM (1985). The effect of digestibility values of resources on the reliability of food habit studies from fecal analyses. Canadian Journal of Zoology 63(9):2183-2186.

Carrière S (2002). Photographic key for the microhistological identification of some Arctic vascular plants. Arctic 55(3):247-268. 
176

Chaurasia OP, Singh B (1998). Cold desert plants. Vol. 4, Zanskar valley. Field Research Laboratory, DRDO, Leh (J \& K) pp 60.

Chaurasia OP, Singh B (2001). Cold desert plants. Vol. 5, Suru valley. Field Research Laboratory, DRDO, Leh (J \& K) pp 63.

Chaurasia OP, Khatoon N, Singh SB (2008). Field guide to the floral diversity of Ladakh. WWF-India pp 198.

Dusi JL (1949). Methods for the determination of food habits by plant micro-techniques and histology and their application to cottontail rabbit food habits. The Journal of Wildlife Management 13:295298.

Ellis BA, Mills JN, Glass GE, McKee KT Jr, Enria DA, Childs JE (1998). Dietary habits of the common rodents in an agro ecosystem in Argentina. Journal of Mammalogy 79:1203-1220.

Green MJ (1987). Diet composition and quality in Himalayan musk deer based on fecal analysis. The Journal of Wildlife Management 51(4):880-892.

Holechek JL, Gross B (1982). Training needed for quantifying simulated diets from fragmented range plants. Journal of Range Management 35:644-647.

Holechek JL, Vavra M, Pieper RD (1982a). Botanical composition determination of range herbivore diets: a review. Journal of Range Management 35(3):309-315.

Holechek JL, Gross B, Dabo SM, Stephenson T (1982b). Effects of sample preparation, growth stage, and observer on microhistological analysis of herbivore diets. The Journal of Wildlife Management 46:502-505.

Holechek JL, Vavra M (1981). The effect of slide and frequency observation numbers on the precision of microhistological analysis. Journal of Range Management 34(4):337-338.

Hurst LA, Beck CA (1988). Microhistological characteristic of selected aquatic plants of Florida with techniques for the study of Manatee food habits. U.S. Fish Wildlife Service Biological Report 88(18):1145.

Ilyas O, Khan JA (2004). Food habits of barking deer (Muntiacus muntjak) and goral (Naemorhedus goral) in Binsar Wildlife Sactuary, India Mammalia 68:1-11.

Javed A, Ahmad M, Zafar M, Sultana S, Khan MA, Arshad M (2012). Palyno-anatomical studies of Clematis L. (Ranunculaceae) from Poonch valley AJK, Pakistan. The Journal of Animal \& Plant Sciences 22(4):1173-1176.

Johnson MK, Wofford H, Pearson HA (1983a). Microhistological techniques for food habits analysis, US Department of Agriculture, Forest Service, Southern Forest Experiment Station. New Orleans, Research paper SO-1999.

Johnson MK, Wofford H, Pearson HA (1983b). Digestion and fragmentation: influence on herbivore diet analysis. The Journal of Wildlife Management 47:877-879.

Lindström LI, Mújica MB, Bóo RM (1998). A key to identify perennial grasses in central Argentina based on microhistological characteristics. Canadian Journal of Botany 76(8):1467-1475.
Lodé T (1996). Polecat predation on frogs and toads at breeding sites in western France. Ethology Ecology and Evolution 8(2):115-124.

Mátrai K, Altbäcker V, Hahn I (1998). Seasonal diet of rabbits and their browsing effect on juniper in Bugac Juniper Forest (Hungary). Acta Theriologica 43(1):107-112.

Metcalfe CR, Chalk L (1950). Anatomy of the dicotyledons. Clarendon Press, Oxford.

Polunin O, Stainton A (1997). Flowers of the Himalaya. Oxford University Press pp 610.

Prabhakar M (2004). Structure, delimitation, nomenclature and classification of stomata. Acta Botanica Sinica - English Edition 46(2):242-252.

Saheed SA, Illoh HC (2010). A taxonomic study of some species in Cassiinae (Leguminosae) using leaf epidermal characters. Notulae Botanicae Horti Agrobotanici Cluj-Napoca 38(1):21-27.

Satakopan S (1972). Keys to the identification of plants remains in animal droppings. Journal of the Bombay Natural History Society 69(1):139-50.

Shoeb M (2011). An ecological reconnaissance survey of mammalian fauna of Rangdum Valley, Kargil. Aligarh Muslim University, Aligarh, MSc Dissertation pp 63.

Shrestha R, Wegge P (2006). Determining the composition of herbivore diets in the trans-Himalayan rangeland: A comparison of field methods. Rangeland Ecology \& Management 59(5):512-518.

Shrestha R, Wegge P, Koirala RA (2005). Summer diets of wild and domestic ungulates in Nepal Himalaya. Journal of Zoology 266(02):111-119.

Smith AD, Shandruk LJ (1979). Comparison of fecal, rumen and utilization methods for ascertaining pronghorn diets. Journal of Range Management 32(4):275-279.

Torres, N, Sàez L, Rossellò JA, Blancé (2000). A new Delphinium subsp. from Formentera (Balearic Islands). Botanical Journal of Linnean Society 133:371-377.

Uresk DW (1986). Food habits of cattle on mixed-grass prairie on the Northern Great Plains. Prairie Naturalist 18(4):211-218.

Wegge P, Shrestha AK, Moe SR (2006). Dry season diet of sympatric ungulates in lowland Nepal: competition and facilitation in alluvial tall grassland. Ecological Research 21(5):698-706.

Wingard GJ, Harris RB, Pletscher DH, Bedunah DJ, Mandakh B, Amgalanbaatar S, Reading RP (2011). Argali food habits and dietary overlap with domestic livestock in Ikh Nart Nature Reserve, Mongolia. Journal of Arid Environments 75:138-145.

Yagueddú C, Comparatore V, Paoletti G (2009). Identification of six Papilionaceae species by epidermal characterstics: Microanalysis of hand composed mixtures. Bulletin of the Botanical Society of Argentina 44(3-4):305-315.

Yasmin G, Khan MA, Shaheen N, Hayat MQ (2010). Taxonomic significance of leaf epidermal anatomy of selected Persicaria Mill. species of family Polygonaceae from Pakistan. African Journal of Biotechnology 9(25):3759-3768. 